\title{
ÚTKERESZTEZŐDÉSBEN
}

\section{A DEMOGRÁFIA: POPULÁCIÓ HELYETT TÁRSADALMAK, MENNYISÉGHEZ MEGÉRTÉS}

\author{
BARNA TÍMEA \\ Pécsi Tudományegyetem Demográfia és Szociológia Doktori Iskola
}

Beérkezett: 2021. január 26., elfogadva: 2021. április 8.

Véronique Petit: Counting Populations, Understanding Societies: Towards an Interpretative Demography. Dordrecht, London, 2013. Springer, xiv + 208 pp. DOI: 10.1007/97894-007-5046-3

„...A demográfusok azt hiszik, hogy az antropológia hozzájárulása demográfiai tudásunkhoz az etnográfiai leírásban rejlik: annak bemutatásában, hogyan élnek, gondolkodnak a reproduktív viselkedésükben (is) mások. Pedig az antropológia éppen az elméletalkotás terén tudja leginkább gazdagítani a demográfia magyarázóerejét." (Greenhalg 1995.)

Véronique Petit francia demográfus, aki számos fekete-afrikai országban folytatott népességkutatásokat több mint húsz éven át, jelen könyvében a demográfia tudományába igyekszik kritikai betekintést nyújtani, saját kutatási eredményeit és tapasztalatait felhasználva. A könyv legfőbb célkitüzése annak meghatározása, hogy az antropológia és a demográfia hogyan kapcsolódhat össze a populációról és a fejlődésről szóló újabb kutatásokban annak ellenére, hogy az ismeretelmélet helye és szerepe, a megismerés módszereinek mikéntje nagy mértékben eltér a két tudományban. A legtöbb demográfus a populációt vizsgálja, és az adatgyüjtés áll tevékenysége középpontjában, ezzel is hangsúlyozva a mérés fontosságát. Ezek a mérések jellemzően a születések, halálozá- sok, házasságkötések, valamint a migráció területére vonatkoznak. Az emögött megbúvó nézet vagy általánosítás az, hogy ha az eseményekhez kapcsolható egyéneket összeadjuk, eljuthatunk a teljes érintett populációhoz. Ezzel a statisztikai általánosítással száll szembe a szerző. Véleménye szerint a számszerüsítés még nem jelenti automatikusan a demográfia tárgyát képező populáció egészére vonatkozó állítások helyességét, hiszen a népesség jelentéstartalma eltérő korokban, területeken és kultúrákban más és más, közel sem homogén. Véronique Petit szerint a demográfusoknak el kellene mozdulniuk egy „megértő demográfia” felé, ahol a számolás és a megértés, értelmezés egyenlő súlyt kap. Populáció helyett szerinte célszerübb lenne társadalomban gondolkodni, és a társadalmi, családi kötelékek, kapcsolatok összességére helyezni a kutatások fókuszát. Fontos ez azért is, mert az egyéneket hálózatok, közösségek, egymásra hatások kapcsolják össze, és ez a társadalmi kontextus határozza meg az egyéni viselkedést, érzelmeket, tetteket.

A fenti kontextus figyelembevételével folytatott vizsgálatokhoz Petit szerint a 
helyi, mikroszintű megközelítés lehet egy alkalmas módszer. Ennek további előnye, hogy segítségével az értelmező szempontok, a köztes változók sokkal szélesebb körét ismerhetjük meg, és megragadhatjuk az adott társadalom szociokulturális, demográfiai, gazdasági és politikai mechanizmusait. Nem szabad a demográfiai folyamatokat kizárólag azok biológiai dimenzióira (pl. születés, halálozás) szükíteni, megfeledkezve a szociokulturális dimenziókról. Csakis egy multidiszciplináris megközelítés segítségével ragadhatjuk meg a demográfiai folyamatok összetettségét, érthetjük meg a vizsgálati egységek és a különböző témák komplex természetét. Különösen célravezető lehet a demográfiai és az antropológiai szempontok kombinálása, akár a problémafelvetésben, akár a megfelelő módszer kiválasztásában, vagy akár az összegyüjtött adatok elemzésében.

Bár az antropológiai demográfia elismertsége növekedett az utóbbi évtizedekben, még mindig nem számít mainstream tudománynak. A kötet e mellett az „új” diszciplína mellett érvel, bemutatja főbb tudományos értékeit, mindvégig hangsúlyozva, hogy az antropológiai demográfia nem keverendő össze a kvalitatív módszerek használatával, és nem is redukálható pusztán azokra. Az antropológiai demográfia segítségünkre lehet, ha a hagyományos adatfelvételi módszerek elégtelennek bizonyulnak, vagy amikor a klasszikus elméleti magyarázó modellek érvényessége megkérdőjeleződni látszik. A terepmunka módszerének minél szélesebb körü átvétele, a mikrodemográfia elterjedése hozzájárulhat a demográfia módszertani eszköztárának gazdagításához, valamint lehetőséget teremthet a kultúra fogalmának beemelésére a magyarázómodellekbe.

$\mathrm{A} z$ antropológiai demográfiában a kutatók személyes ismeretséget alakítanak ki a vizsgált közösséggel, és jellemzően részt- vevő megfigyelést alkalmaznak. Ezáltal jobban megérthetővé válik a demográfiai esemény mögöttes tartalma, a mozgató erő. Ennek a megértésnek a kiemelt szerepére, jelentőségére hívja fel Petit a figyelmet. Antropológiai megközelítéssel élve a statisztikai adatokat kontextusba hozhatjuk, rávilágíthatunk a sokszor egyértelmünek vélt fogalmak kultúráktól függő, eltérő jelentéseire, és nem utolsósorban a hagyományos módon gyüjtött adatok érvényességének ellenőrzésére is lehetőséget kaphatunk.

$\mathrm{A} z$ antropológia felé fordulást a Princeton-projekt (Princeton European Fertility Project) eredményei katalizálták, melyek hatására megjelent a kultúra mint magyarázó változó. A belga demográfus, Ron Lesthaeghe nevéhez füződő érdemi kísérlet arra vonatkozott, hogy a kultúrát be lehessen vonni a hagyományos demográfiai felmérések kérdései közé. Véronique Petit szerint mind az antropológusok, mind a demográfusok részéről elindult a közeledés, sőt valamiféle intézményesítés is megkezdődött, azonban a két tudomány együttműködése útjában jelenleg még áll néhány akadály. Míg a demográfiában legtöbbször mérésorientált megközelítéssel, nézettel találkozunk, addig az antropológia értelmező, magyarázó világlátású tudomány. A legfontosabb annak megállapítása, hogy a kultúra milyen értelmezését célszerű használni, és hogyan lehet operacionalizálni a demográfiai folyamatok kutatásában. Megoldandó feladat a vegyes módszert alkalmazó kutatások egymással összehasonlíthatóvá tétele. A számítások és a megértés összekapcsolásának várható végeredményeként egy szintre hozhatjuk a mérést és a magyarázatot, értelmezést. Petit a két tudomány közelítésének nehézkes mivoltát az episztemológia eltérő helyének és szerepének tulajdonítja, valamint az eltérő hagyományoknak, intézményi fejlődés- 
történetnek és nem utolsósorban a különböző gyakorlati módszertannak. Nyugatafrikai tapasztalataira, eredményeire alapozza véleményét, hogy az antropológia és a demográfia egymást kiegészítő kutatási eszközöket és modelleket használ, ezért egyik diszciplína sem hagyhatja figyelmen kívül a másik szerepét a kutatási folyamatokban, illetve érvel azon állítása mellett, miszerint a termékenységgel, szegénységgel, migrációval kapcsolatos viselkedésváltozásokat nem lehet leírni és elemezni bizonyos kulturális faktorok figyelmen kívül hagyásával.

A könyv hét fö fejezetből áll. Az első fejezetben Petit az ismeretelméletnek tulajdonított szerep alapján röviden összehasonlítja az antropológiát és a demográfiát. A megismerés módszereit keresi, a tudás megszerzésének legbiztosabb útját vizsgálja a két tudomány nézőpontjából. A második fejezetben áttekintést ad a demográfia történetéről és intézményesüléséről Franciaországban, vizsgálja a demográfia fejlődését. Ezek után arról olvashatunk, hogy miért fogadták ellentmondásosan a demográfiát a társadalomtudományok területén. A szerző a negyedik fejezetet a populáció történelmi szempontú vizsgálatának szenteli. A következő részben az olvasó betekintést kaphat az antropológia és a demográfia párhuzamos történetébe, melynek során a két tudomány közeledett egymáshoz, még akkor is, ha ez a kapcsolat a különböző korszakok és kutatási fókuszok függvényében hol erősödött, hol gyengült. $A$ hatodik fejezetben bemutatott afrikai példák azt mutatják, hogy a termékenységgel, szegénységgel vagy migrációval kapcsolatos viselkedésbeli változások sem értelmezhetők anélkül, hogy figyelembe ne vennénk kulturális tényezőket. A mikrodemográfia fejlődése hozzájárulhat a kultúra beágyazásához a változók, mérések javítása, az ok-okozati tényezők és az eredmények alaposabb megértésének területén.

A fejezet több példát ismertet, olvashatunk például arról, hogy a szenegáli nők milyen arányban használnak modern fogamzásgátlókat. A hivatalos felmérések, a durva statisztikák a városi nők körében növekvő, a vidéki nők körében viszont rendkívül alacsony és stagnáló arányokat mutattak. Petit viszont arra jött rá, hogy a falvakban élő nők is nagy arányban élnek a modern fogamzásgátlás lehetőségével, csak másként számolnak be róla. Jóllehet, tagadták a használatát, a falusi egészségügyi intézmények a modern fogamzásgátlók iránti igény magas szintjéről számoltak be. Ezért Petit újra felkereste ezeket a nőket, és kiderítette, miért nem pontosak a kapott eredmények. Mivel a nők tudták, hogy a fogamzásgátló használatáról szóló pletykák ártalmasak rájuk nézve (a helyi vallási és politikai vezetők pl. nyilvánosan ellenezték a fogamzásgátlók használatát), ezért inkább hamis válaszokat adtak.

Végzetül megemlítem, hogy a kötetben hazai vonatkozásra is bukkanhatunk. Petit észak-magyarországi aprófalvakban (Lápos, Bordó, Rakaca) végzett kutatásokat ismertet a romák termékenységi magatartásáról, amelyek szintén megmutatják, milyen jelentős hozadéka lehet az antropológiai demográfiai szemléletnek.

$\mathrm{A} z$ említett esettanulmányokból kiderül egyrészt, hogy a társadalmi rendszer jelentős hatással van a termékenységi magatartásra, másrészt az is, hogy ez önmagában még nem kielégítő magyarázat, a termékenységi magatartás hátterében húzódó motivációk jobb megértéséhez a kulturális kontextus ismerete is szükséges. Az eltérő kulturális hatásoknak nagy szerepük van abban, hogy közel azonos körülmények között élö, azonos etnikai csoporthoz tartozó nők egymástól eltérő cselekvési terv szerint alakítják termékenységi magatartásukat. 
A bemutatott kutatások eredményei és tapasztalatai meggyőző bizonyítékot szolgáltatnak arra, hogy a demográfiai események kutatásakor a demográfiai viselkedést meghatározó, mögöttes tartalom feltárása és megértése is szükséges.

\section{IRODALOM}

Anthropology Theorizes Reproduction: Integrating Practice, Political Economic, and Feminist Perspectives. In: Susan Greenhalgh (ed.) Situating Fertility. Anthropology and Demographic Inquiry. Cambridge, Cambridge University Press. pp. 3-28. Online megjelenés: 2009. december. www.cambridge.org/core

A cikk a Creative Commons Attribution 4.0 International License (https://creativecommons.org/licenses/ by-nc/4.0/) feltételei szerint publikált Open Access közlemény, melynek szellemében a cikk bármilyen médiumban szabadon felhasználható, megosztható és újraközölhető, feltéve, hogy az eredeti szerző és a közlés helye, illetve a CC License linkje és az esetlegesen végrehajtott módosítások feltüntetésre kerülnek. 